\title{
The Multetta Debris Fan, Eastern Swiss Alps: A 500-year Debris Flow Chronology
}

\section{F. Baumann}

\section{and $K . F$. Kaiser}

Swiss Federal Institute for Forest, Snow and Landscape Research, $\mathrm{CH}$ 8903 Birmensdorf and Department of Geography, University of Zurich, CH8057 Zurich, Switzerland.

kaiser@wsl.ch;

kf.kaiser@access.unizh.ch

\begin{abstract}
The opening up of the Alps for tourism has increased the risk potential from natural hazards, one of the greatest of which is debris flows. Since 1996 we have been studying the debris fan of Multetta above Tschierv in Val Müstair in the Swiss Alps to determine the dates and hence the frequency of debris flows. Abrupt growth changes, impact scars, and the formation of adventitious roots allowed precise dating by dendrochronological methods in cases where tree ring characteristics occurred synchronously in several different trees. Six debris flows since the late 15 th century could be recognized, occurring at the end of the 15 th century, and in 1573, 1655, 1784, 1958, and 1989. The debris deposited during the past $500 \mathrm{yr}$ has formed a layer about $5 \mathrm{~m}$ deep. Two further debris flows were identified through scars formed in 1759 and 1837. A greater frequency of scars between the mid-18th century and the end of the 19th century indicates considerably higher morphological activity during the last peak of the Little Ice Age.
\end{abstract}

\section{Introduction}

The progressive opening up of the Alps for tourism is resulting in an increasing potential risk from natural hazards such as debris flows at a time when changes in climate may be altering the frequency of such mass movements. Quantifying such events, which occur at infrequent intervals, remains a serious problem. Alestalo (1971) described how past geomorphologic events may be identified through studying trees and tree stands affected, while Shroder $(1978,1980)$ reconstructed the slow creep of a wooded, volcanic debris slope in Utah, U.S.A., by recording variations in tree-ring sequences. Strunk (1995) quantified debris flows in the Italian Dolomites on the basis of the spruce stands growing on the debris fans. Costa (1984) and Johnson and Rodine (1984) have provided comprehensive general reviews of debris flows.

The Multetta debris fan lies at about $1870 \mathrm{~m}$ a.s.l. near Tschierv, Val Müstair, in the Swiss Alps (Figs. 1, 2). The east side of the fan is stocked with an open stand of mountain pine (Pinus mugo), while the west side bears trees only on its lower half where the stands are separated by recent debris flow channels.

The aims of this study are (1) to identify debris flows on the basis of stratigraphy; (2) to date such events by means of dendrochronological evidence; and (3) to determine the frequency of debris flows.

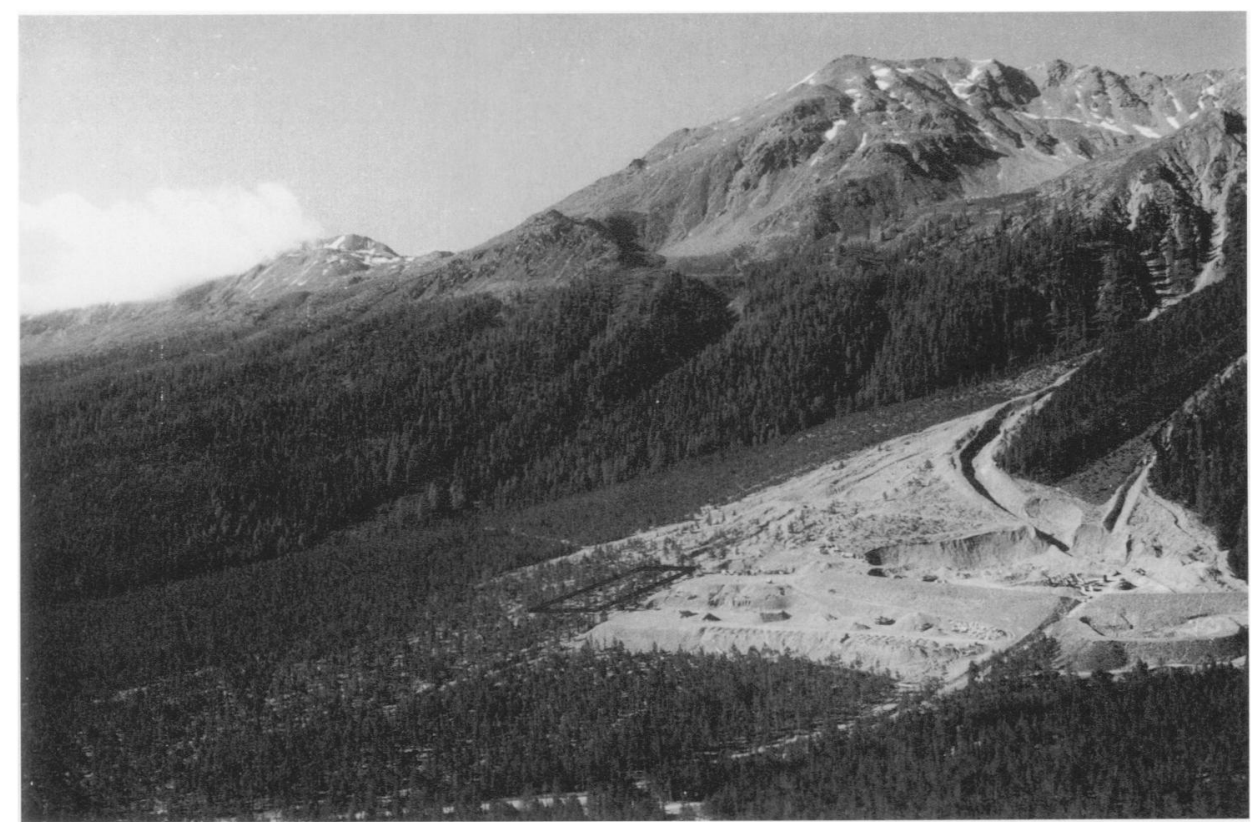

FIGURE 1. View of the Multetta debris fan and the study site from the Ofenpass road. View to south. The box outlines the area of Figure 3. 


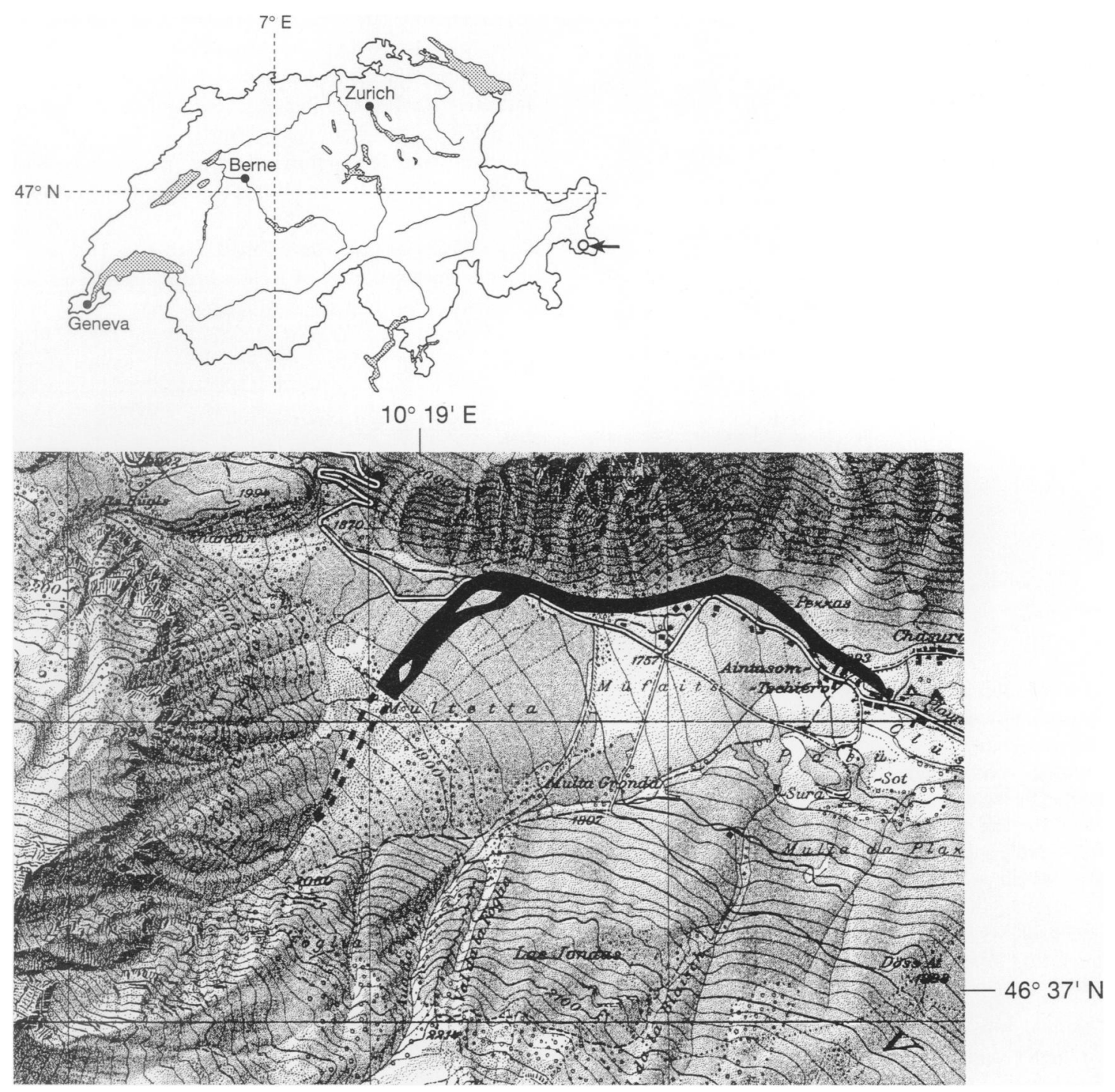

FIGURE 2. The study site within Switzerland: The map shows catchment area, debris fan, and extension of the exceptional 1989 debris flow (Reproduced by courtesy of the Federal Office of Topography, Berne, February 1999). The space between the grid lines is $1 \mathrm{~km}$ wide.

\section{Study Area}

Material from the mountain pine (Pinus mugo), with its extreme adaptability and long life span, allows the construction of chronologies of up to four or more centuries. This was a major factor influencing the selection of the Multetta debris fan of Tschierv.

The observations in this particular study were conducted over an area of some $700 \mathrm{~m}^{2}$ on the active, western flank of the fan (Figs. 1, 2). The fan is traversed by a recent debris flow channel in which all the trees had been topped-30 within the study area proper and a further 27 trees, 7 of which were already dead, on the debris flow levees or beyond the channel itself. This admittedly small site was chosen because only in this limited area did the eroded channel enable us to dredge $2 \mathrm{~m}$ deeper than anywhere else on the forested part of the fan and thus reconstruct a record as long as possible.

\section{Methods}

\section{ANALYSIS OF TREE RINGS}

The trees on the study plot were mapped and surveyed (Fig. 3 ). Either discs or cores were then taken for subsequent obser- vation and measurement of the tree rings. Cores were taken from living trees at $1.50 \mathrm{~m}$ above ground, at least one core on the mountain and another on the downhill side. In case of missing rings, two more cores were taken from the lateral sides. Discs were sawn from the stems of excavated trees. These last were taken both from sections from which adventitious root suckers had sprouted and from the segments between (Fig. 4). In general discs are a better mean than cores to detect missing rings, overgrown scars and other anomalies in the tree-ring pattern. The examination also included tree-ring width measurements and inspection for tree ring characteristics that could be associated with debris flow activity: abrupt growth changes, scars (Fig. 5) and the occurrence of adventitious roots (Fig. 4).

\section{Abrupt Growth Changes}

Stems suddenly covered by a debris flow normally react with an abrupt growth reduction, which may persist for years because of the change in conditions. However, abrupt growth reductions can result from other ecological events (Schweingruber, 1993; Strunk, 1995). The mountain pines of Multetta often display abrupt growth reductions that do not correlate with 


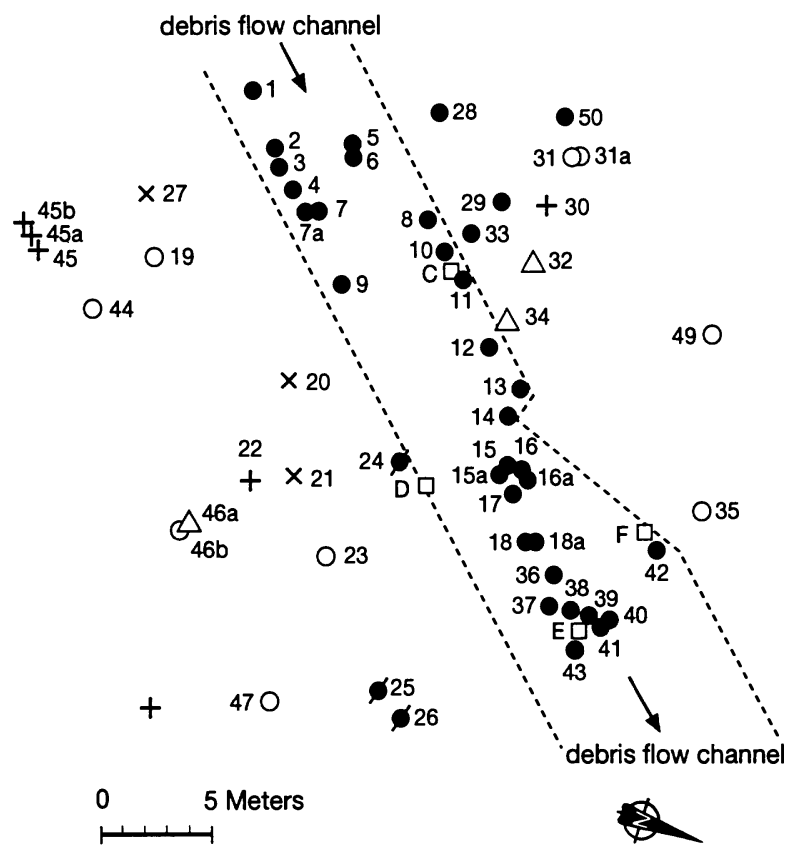

$x$ abrupt growth reduction

+ abrupt growth release

$\circ$ no reaction detectable

$\triangle$ growth release already in the early fifties

- tree uprooted by the debris flow

$\checkmark$ tree dead at the time of coring

$\square$ tree totally buried, detected by excavation

47 number of tree (surveying)

FIGURE 3. Locations of trees at the study site and their reactions to the debris flow of 1958.

aggradation by a debris flow. In this study, the frequency and periodicity of such phenomena varied greatly from tree to tree. None of the marked growth reductions in any one of the trees examined crossdated with those observed in any of the others. Abrupt growth changes did not seem to be a suitable tool to determine debris flows in this case.

In contrast, large debris flows may even trigger an increased growth rate as injuries induce emergency release of reserves, because unexploited soil nutrient layers are suddenly activated, or because competition is reduced by the elimination of adjacent trees. Yet in other cases, aggradation by a debris flow may not produce any observable difference in the pattern of ring width.

\section{Impact Scars}

Debris flows may cause scars on the tree trunk due to mechanical damage to the bark or the cambium. The cambium of a damaged tree produces scar tissue over the wound almost at once or during the next growth period. Scars reveal the exact date of a particular event, and thus provide the most precise figures for dating (Shroder, 1980; Clague and Souther, 1982; Strunk, 1995) (Fig. 6). Scars also provide information on the maximum depth of a debris flow and the grain size of the transported material (Alestalo, 1971; Shroder, 1980; Clague and Souther, 1982; Strunk, 1995). Large, rough rocks induce deep wounds whereas flows sweeping along a large proportion of finegrained sand at high speed may abrade the entire bark and cambium. The locations of the scars on the tree also help in the reconstruction of flow direction.
It should, however, be borne in mind that not every scar on a tree trunk is produced by debris flow impact. At Multetta, some injuries may have been caused by rockfall, snow avalanches, and damage by antler rubbing. Rockfall and snow avalanches can be excluded in the study area. Antler rubbing produces rings at about the same level all round the stem. Lightning strikes usually leave vertical scars, sometimes reaching from the top to the bottom of the stem. Scars left by debris flows are usually irregularly shaped and generally only found on the inner side of the levees and on the lower part of a flow channel and are therefore easy to identify, as long as they are not buried. For these reasons, scars seem to be the best tool for dating debris flows (Strunk, 1995).

\section{Adventitious Roots}

Pinus mugo produces adventitious roots at the basal part of the stem covered by a debris flow (Fig. 4); these develop endogenously from the cambium, from dormant buds (Alestalo, 1971; Fink, 1980), or from the margin of callus tissue covering wounds (Nägeli, 1931; Fink, 1980). Adventitious roots make it possible to trace burial by debris: their age reveals the latest date of the debris flow, their height the maximum depth of the deposit (Alestalo, 1971). Adventitious roots develop mainly directly under the surface of the debris cover, but may also form at lower points on the stem (Strunk, 1995) (Fig. 4). Should a burial event occur during the growth period the tree may produce adventitious roots immediately, or in the following year. Strunk (1995) observed time lapses of up to several decades in other cases. The dating of a deposit therefore must be based on the age of the oldest adventitious roots.

In the Multetta study, ring counting in the roots was particularly important because it provided the only means of dating one of the deposits. The prerequisite for this method is that the adventitious roots be well formed with a large diameter and sufficiently wide, clearly distinct rings close to the stem itself (Fig. 4). The exact point of origin of the root can only be identified by means of very precise work with a saw and an abrasion belt. The polished stem disc must then be carefully examined to identify the first tree ring from which the root actually initiated. The procedure is extremely laborious and could only be applied in a few cases; it was especially unsuccessful for adventitious roots of small diameter (mostly with ring width $<0.05 \mathrm{~mm}$ ).

\section{Results}

\section{CHRONOLOGY OF DEBRIS FLOWS}

\section{6th Century}

The oldest debris flow evidence at Multetta was found at a depth of about $6 \mathrm{~m}$ below the present soil surface (Fig. 4). None of the trees penetrated the soil to a deeper level, so it was here that the oldest trees were found rooted. It was probably after the aggradation, most likely through a debris flow, that the present cohort of trees began to grow on the study site. Three of the excavated trees (nos. 2, 6, and 7) were rooted in the deepest buried soil layer. All three survived into the 20th century although they were subsequently uprooted by debris flows in 1958 or 1989 (Figs. 1, 2, 4, 7).

The pith of tree no. 6 was dated at AD 1501 that of tree no. 2 at 1520 . The time lag between a debris flow and the germination of the first tree depends both on the tree species and on environmental conditions, and varies greatly. Strunk (1995) estimated a mean lapse of about 8 yr before the first trees ger- 


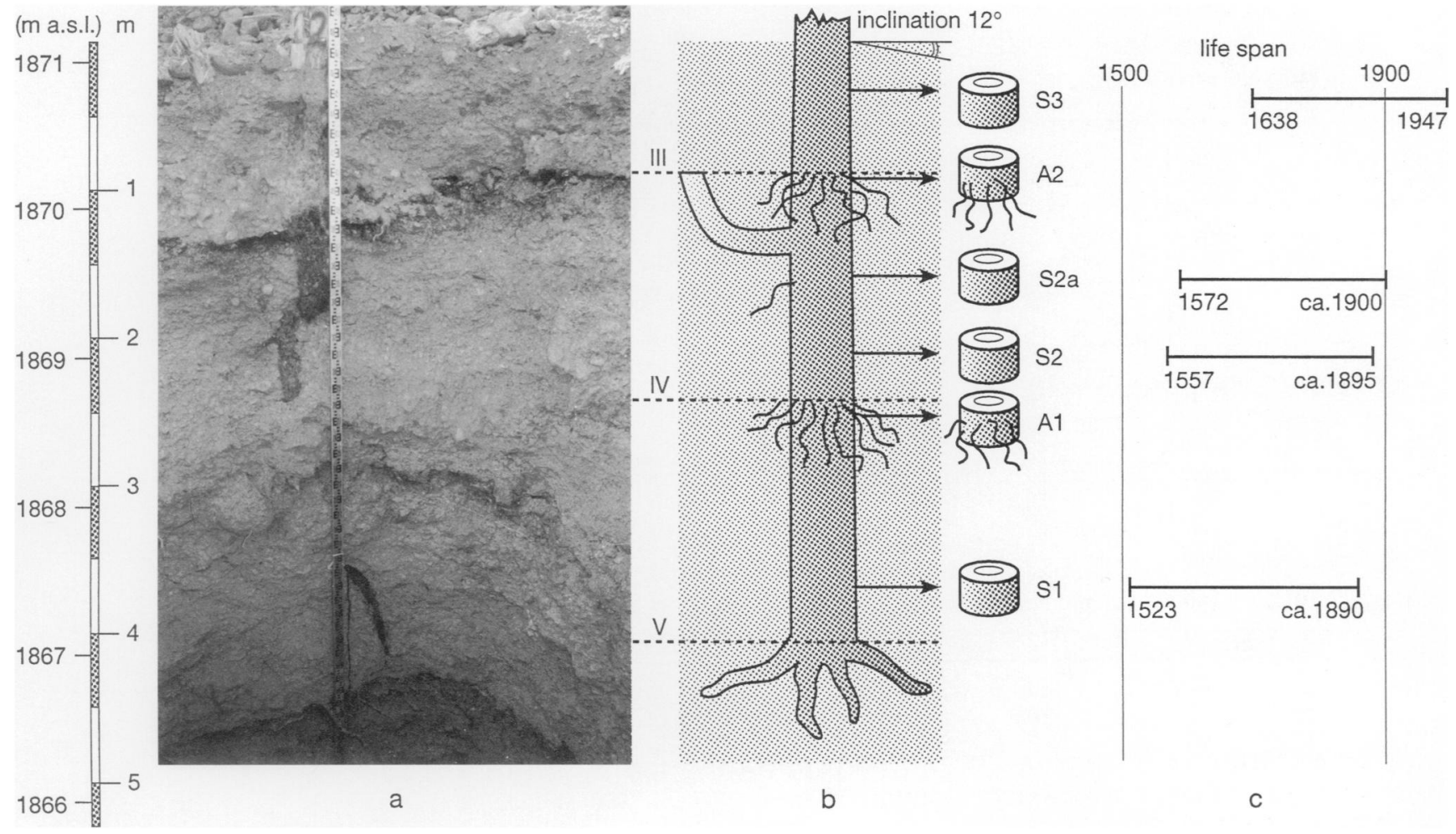

FIGURE 4. Summary plot of debris flow evidence at tree No. 2: (a) Profile displaying three buried soils and adjoint adventitious root system, (b) sampling of tree No. 2 with its three stories of root systems, (c) life span of tree No. 2 at different levels.

minate. No new soil formation could be identified on top of the deposit. If the absence of a fossil soil was not the result of erosion, the elapsed time period was probably a few years or at most decades. Consequently the debris flow may have occurred around the end of the 15th century. There is no evidence of a phase of erosion.

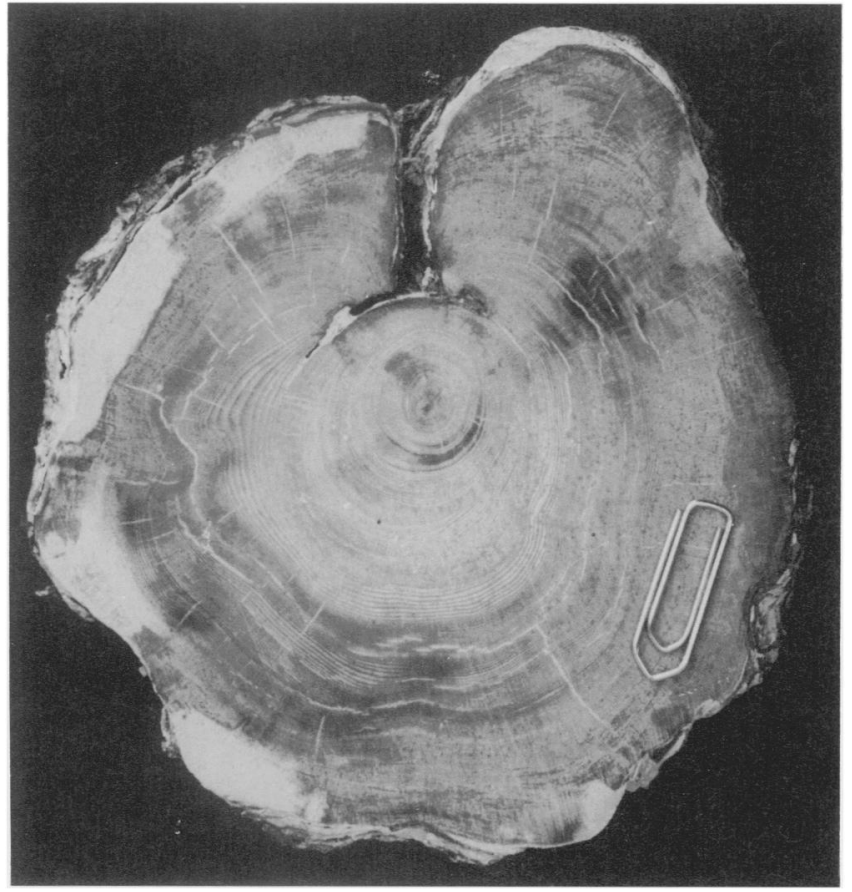

FIGURE 5. Cross-section S1 of tree No. 2 showing the scar of AD 1573 (cf. Fig. 4)
The numerous growth reductions and zones of compression wood seen in the early growth years of the oldest trees indicate that the slope was still quite unstable during the first decades after the actual flow. Towards the end of the 16th century there was a slight aggradation, indicated only by a few adventitious roots on tree no. 6 . The date of the event is probably related to a large scar dated 1573 (Figs. 5, 6).

\section{7th Century}

During the first half of the 17th century, tree growth increments were very regular. Except for a scar found on tree no. 7 and dated 1606, no injuries were observed. In the middle of the 17th century a large debris flow buried the stand, and all the trees affected formed adventitious roots at the corresponding level. The analysis of these roots was difficult, since the tree rings were sometimes extremely narrow and their point of origin could not be determined. Six of the trees were already growing when the flow occurred. For two of them the date of sprouting of the adventitious roots could only be roughly estimated (tree no. 6 about 1650, tree no. 34 about 1650-1665). For tree no. 2 the ring count showed 1655 as the year of origin, while tree no. 7 displayed a particularly thick adventitious root sprouting in 1669 , which is considerably later than that of other roots. The date of root sprouting in trees no. 10 and no. 33 could not be determined (Figs. 3, 7). The debris flow must have occurred in 1655 or shortly earlier. It is quite possible that adventitious roots originating in 1669 may be related to this event. The year of each event may therefore be roughly estimated from the age of the oldest adventitious root in each cohort.

Many mountain pines germinated on the debris deposited by the flow of 1655 (Fig. 7). Most of the trees excavated were rooted in this layer. Asynchronous abrupt growth reductions and 

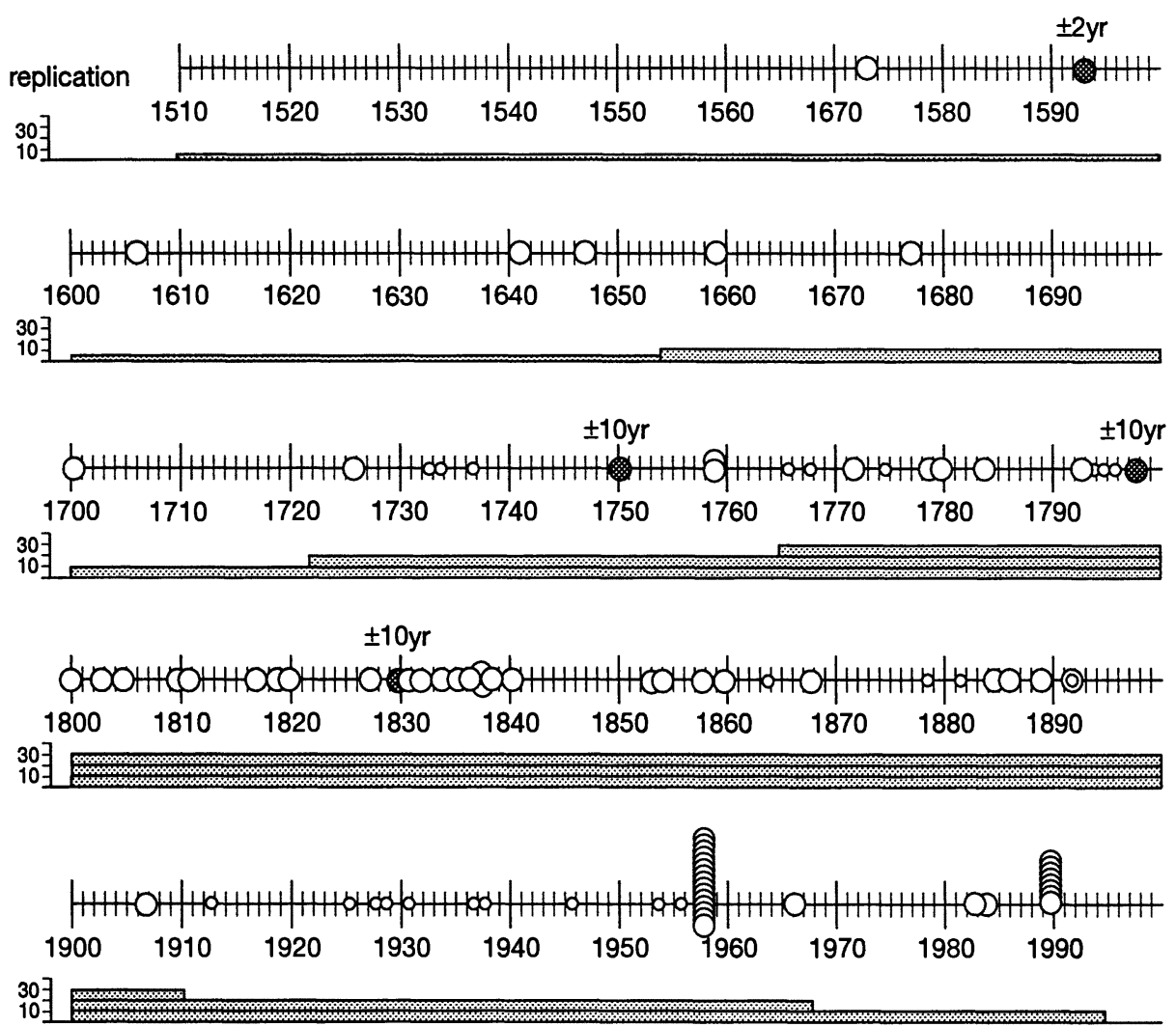

legend:

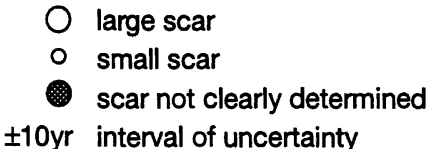

FIGURE 6. Time plot of scars.

scars were dated to $1641,1647,1659,1677$, and 1682 , indicating active slope movement from 1640 up to the end of the century (Fig. 6), which seems to have slowed by the beginning of the 18 th century.

\section{8th Century}

The first half of the 18th century seems to have been relatively tranquil, but this quiet period was followed by phases of increased debris flow activity. A large scar on tree no. 6 was dated at 1750, and injuries in 1759 were observed on two other trees (Fig. 6). Injuries also occurred repeatedly during the following period until the massive debris flow of 1784 buried the trees even deeper. Only tree no. 34 exhibits a large scar from that year. Ring counts on particularly evident adventitious roots revealed 1785 (tree no. 42), 1786 (tree no. 2), and 1795 (tree no. 33) as years of sprouting (Figs. 4, 7, 8).

\section{9th Century}

Between 1784 and the end of the 19th century, 40 damaging impacts occurred to trees on the study site, about threequarters of them in the region of the adventitious roots formed by trees no. 6 and no. 34 in 1784 (Figs. 6, 7). Such wounds could only have been inflicted by a subsequent exposure of the roots. This also explains the presence of poorly formed, dead adventitious roots on these trees. Between 1800 and 1820 , eight deep scars were formed, and a further 11 between 1827 and 1840
(Fig. 6). After 1840 the disturbances gradually attenuated, although nine further injuries occurred before the end of the century.

\section{0th Century}

Only one large scar, formed in 1907 , was observed for the first half of the 20th century. Ring formation was fairly regular. Nevertheless the development of the 8-cm-thick soil layer, buried in 1958, must almost certainly have begun before 1907 (Fig. 4).

In 1958 a debris flow uprooted a large number of trees, swept them away and covered this newly formed soil with 1 to $2 \mathrm{~m}$ of debris. This event is clearly reflected in the tree-ring pattern. Hardly any of the trees in the existing flow path escaped severe damage (Figs. 6, 7). This indicates that the present channel had been eroded and its levees deposited by 1958 (Fig. 3, 7).

The flow of August 1989 deepened the channel and raised its levees. It uprooted yet another eight trees and inflicted further damage on those growing on the channel banks (Figs. 2, 7). It also exposed adventitious roots formed after 1958 and ripped most of them away. This debris flow deposited far less material in the study area than that of 1958 , since the volume of material involved was greater and therefore swept farther downstream, over the Ofenpass road as far as the village of Tschierv (Figs. $2,7,8)$. 


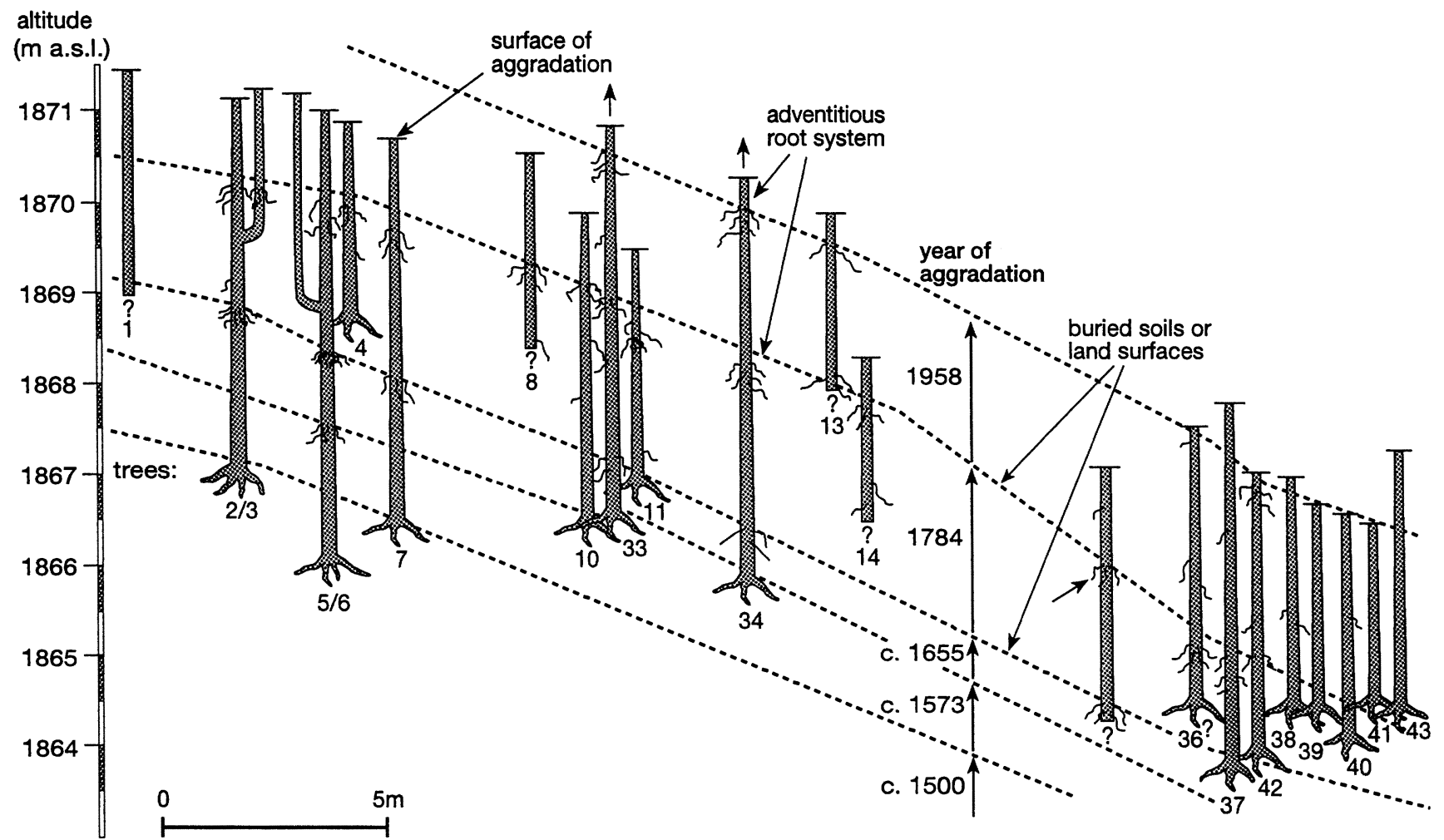

FIGURE 7. Summary longitudinal section through debris flow deposits at the study site showing buried trees, soils or land surfaces, and their maximum ages.

\section{Discussion}

Trees are important indicators of the dates and frequency of debris flows as these occur only episodically in remote places and are seldom observed at first hand. In this study the same methods used by Strunk (1995) in the eastern Alps were applied. The results are discussed here.

According to Strunk (1995), different authors have estimated a time lapse of up to $75 \mathrm{yr}$ before debris flow deposits become recolonized with trees. Strunk estimated an average period of $8 \mathrm{yr}$ before the first trees germinate. Our own findings covering the period 1650 to 1655 indicate that the forest may have begun to regenerate within about $5 \mathrm{yr}$ of each event.

Impact scars above the ground surface give a simple means for mapping and dating, because the flow channel and levees are easy to trace. Where scars have been buried, however, such as those formed in 1784 , precise dating is difficult but still possible, since the course of the debris flow can be reconstructed where a number of trees display scars at the same level, such as those of 1958. Individual scars such as occur on the lower buried sections of trees in the study area can be dated, but not definitely associated with a particular event. Dating becomes more problematic the lower and more deeply buried the injury is, because the tree rings may be so narrow or so decomposed as to be indistinguishable. The increasing number of scars in the late 18th century and the 19th century seems to coincide with the last peak of the Little Ice Age. Only the study of Strunk (1995) in the Italian Dolomites provides results dating so far back. He recognized increased debris flow activity during the same period. He distinguished seven debris flows between 1745 and 1896: after 1745 , after 1763, two undetermined aggradations, $1809 \pm$ $5 \mathrm{yr}, 1865 \pm 2 \mathrm{yr}$, and $1896 \pm 3 \mathrm{yr}$.

As a rule, abrupt growth reductions occurred only irregularly. Further, in parts of the area buried by debris flows we could not observe any changes in growth rate. In addition, trees may react to injury through increased growth due to release of reserves or because competitors are eliminated. Consequently in this study we could draw no definite conclusions from abrupt changes in growth as shown by changes in ring width.

Strunk (1995) found differences from 8 to $18 \mathrm{yr}$ in the sprouting age of adventitious roots within a single soil horizon. It follows that an event can only be dated from the date of sprouting of the oldest adventitious root with any one system. In the debris flows occurring between 1650 and 1655, most of the adventitious roots developed within 1 to $5 \mathrm{yr}$ after the event. The last of this generation of roots originated in 1669, thus exhibiting the maximum age difference of $20 \mathrm{yr}$. Following the debris flow of 1784 the adventitious roots began to sprout after only $1 \mathrm{yr}$ but continued to do so over the following $10 \mathrm{yr}$. In accordance with the results of Strunk (1995), our present study obtained most information on debris flow activity through the examination of adventitious roots.

\section{Conclusions}

Similar tree-ring patterns or combinations of similar characteristics occurring in the same period date a debris flow with reasonable accuracy. Because the area covered by our detailed study was so small, we have almost certainly not registered the entire scope of the debris flow deposited on the fan of Multetta over the past 500 yr. Subsequently we have extended our observations over the entire fan surface in hopes of identifying all the flows together with their courses and extent.

The higher frequency of scar formation between the middle of the 18th century and the end of the 19th century indicates a phase of higher geomorphic activity during the last peak of the Little Ice Age. This could have been caused by fluctuations in 


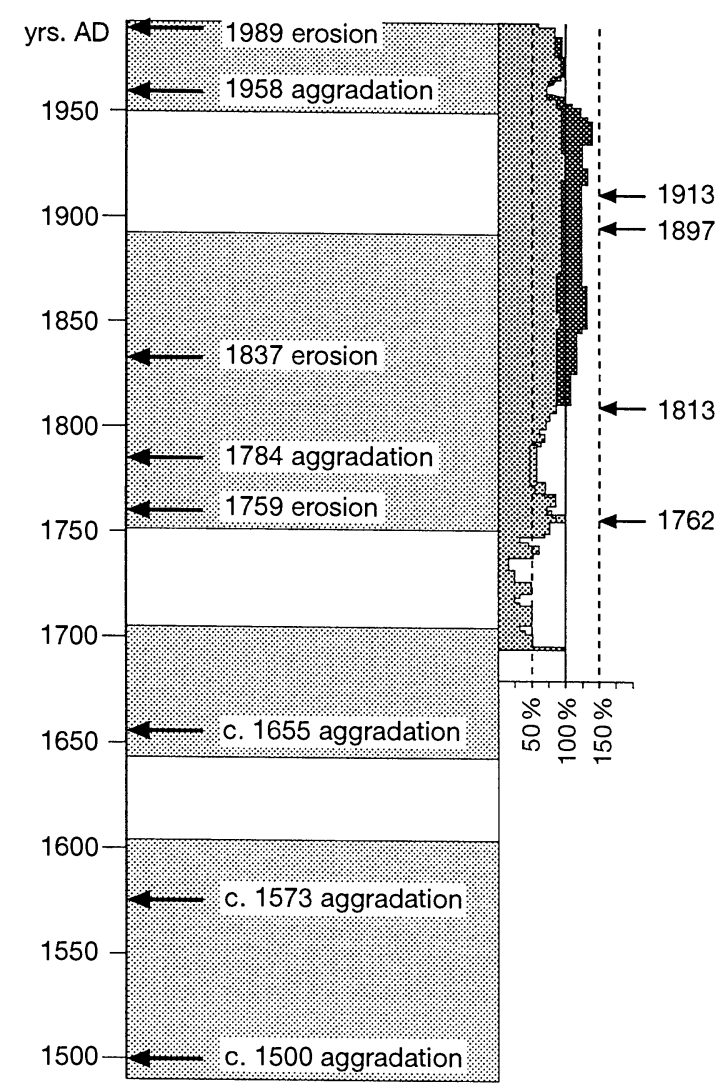

legend:

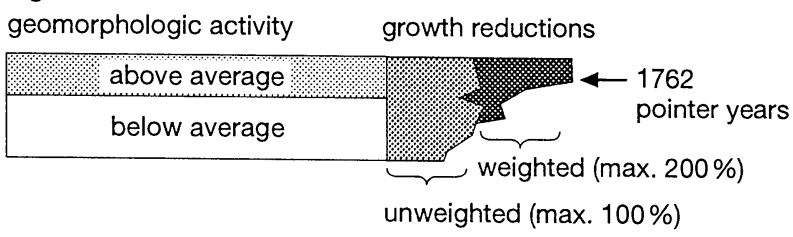

FIGURE 8. Chronology of debris flows, and correlations with inferred phases of geomorphic activity and abrupt growth changes in trees.

the level of permafrost, which was between 100 and $300 \mathrm{~m}$ lower than at present (Haeberli, 1992; Schindler et al., 1993; Haeberli et al., 1997). These fluctuations may have briefly stabilized debris in critical sections of the catchment area, but subsequently rendered it particularly unstable. Consequently a higher number of small debris flows was released into our study area causing the high number of injuries to trees.

\section{Acknowledgments}

The authors wish to thank the following persons and institutions for their help and support: of the Swiss Federal Institute for Forest, Snow and Landscape Research, Director Dr. M. F.
Broggi, Dr. W. Ammann, Prof. F. H. Schweingruber, Dr. W. Keller, Dr. R. Landolt, P. Henseler, and M. J. Sieber; H. J. Weber, District Forest Officer district 26; G. Guler, Forester, Fuldera; Prof. W. Haeberli, Institute of Geography, University of Zurich; of the Direction of the firm Florian Pitsch SA, Tschierv; Dr. A. Petrascheck, Federal Water Authority, Biel; and Prof. U. Schmid, Freudenberg Junior College, Zurich.

\section{References Cited}

Alestalo, J., 1971: Dendrochronological Interpretations of Geomorphic Processes. Societas Geographica Fenniae, Fennia, 105. $140 \mathrm{pp}$.

Clague, J. J. and Souther, J. G., 1982: The Dusty Creek landslide on Mount Cayley, British Columbia. Canadian Journal of Earth Sciences, 19: 524-539.

Costa, J. E., 1984: Physical geomorphology of debris flows. In Costa J. E. and Fleisher P. J. (eds.), Developments and Applications of Geomorphology. Berlin: Springer Verlag, 268-317.

Fink, S., 1980: Anatomische Untersuchungen über das Vorkommen von Spross- und Wurzelanlagen im Stammbereich von Laub- und Nadelbäumen. Diss. Albert-Ludwigs-Universität Freiburg i. Br. 206 pp.

Haeberli, W., 1992: Possible effects of climatic change on the evolution of Alpine permafrost. Catena Supplement 22: 2335 .

Haeberli, W., Wegmann, M., and Von der Mühll, D., 1997: Slope stability problems related to glacier shrinkage and permafrost degradation in the Alps. Eclogae Geologicae Helvetiae, 407414.

Jakob, M., 1996: Morphometric and geotechnical controls of debris flow frequency and magnitude in Southwestern British Columbia. Ph.D. dissertation, University of British Columbia. $232 \mathrm{pp}$.

Johnson A. M. and Rodine J. R., 1984: Debris flow. In Brunsden D. and Prior D. B. (eds.), Slope Instability. Chichester: John Wiley, 257-361.

Nägeli, W., 1931: Adventivwurzelbildung an übererdeten Baumstämmen. Mitteilungen der Eidgenössischen Anstalt für das forstliche Versuchwesen, 16: 129-147.

Schindler, C., Mayer-Rosa, D., Keusen, H. R., Bezzola, G. R., Haeberli W., and Zimmermann, M., 1993: Felsstürze Randa 1991. Cartographie géomorphologique-cartographie des risques-Institut de Géographie Lausanne, Traveaux et recherches, 9: 117-129.

Schweingruber, F. H., 1993: Jahrringe und Umwelt-Dendroökologie. Eidgenössischen Forschungsanstalt für Wald, Schnee und Landschaft, WSL, Birmensdorf. $474 \mathrm{pp}$.

Shroder, J. F., 1978: Dendrogeomorphological analysis of mass movement on Table Cliffs Plateau, Utah. Quaternary Research, 9: 180-185.

Shroder, J. F., 1980: Dendrogeomorphology: review and new techniques of tree-ring dating. Progress in Physical Geography, 4: 161-188.

Strunk, H., 1995: Dendrochronologische Methoden zur Ermittlungen der Murfrequenz und Beispiele ihrer Anwendung. Regensburg: S. Roderer Verlag. 196 pp.

Ms submitted June 1998 